\title{
Impact of Digitization on the Teaching and Learning of Chemistry and Mathematics at the Distance Learning Institute of the University of Lagos
}

\author{
Elom Chukwuemeka Michael ${ }^{1, *}$, Adesoji Adedoyin Oluseyi ${ }^{1}$ \\ ${ }^{1}$ Distance Learning Institute, University of Lagos [*Corresponding author: \\ skygardenslearningcenter@yahoo.com ]
}

\begin{abstract}
This study aimed at examining the impact of digitization in the teaching and learning of Chemistry and Mathematics in open and distance learning (ODL) at the Distance Learning Institute of the University of Lagos. A sample of 122 Chemistry and Mathematics students and lecturers was selected using simple random sampling. Data was collected using a questionnaire and analysed using descriptive statistics and Chi-Square. The findings were that the respondents lacked adequate digitization facilities and exposure. Their utilisation of digital facilities was characterized as low. It is recommended that the Institute makes digitization a matter of ultimate priority and provides funds for staff and student training.
\end{abstract}

Keywords: ICT; E-learning; ODL.

\section{$1 \quad$ Introduction}

Digitization is crucially important to data processing, storage and transmission, because it allows information of all kinds to be carried with efficiency and to be integrated. This is why it is a favoured way of preserving information for many organisations around the world. In the provision, utilization and maintenance of digitization in ODL it is expected that teachers and learners enjoy more comfort, convenience, portability, durability, security and accountability. However, they could also be constrained by limitations on the teachers and learners; manpower, funding, power, security, location, connectivity, information to digitize, hardware and software requirements and so on. Therefore, this research work is planned to identify the major roles of digitization and problems in using digitized learning and teaching. Despite the benefits associated with digitisation, therefore, its impact need not be taken for granted. There is need to investigate the impact 
of digitisation on teaching and learning, even if a host of studies affirm that digitisation is invariably beneficial. This study was conducted to respond to this need, taking the teaching and learning of Chemistry and Mathematics at the Distance Learning Institute of the University of Lagos.

\section{$2 \quad$ Methodology}

Data was collected from a sample of 122 participants who were drawn from a population of 250 students and staff of the Distance Learning Institute of the University of Lagos. This was done using a questionnaire. The questionnaire comprised of two sections, namely, A and B. Section A covered the bio-data of the respondents while Section B, which included 64 items, covered attributes of the impact of digitisation on the teaching and learning of Chemistry and Mathematics. Each of these items was structured on a four point Likert scale ranging from a score of 1 to 4 , with 1 as "Strongly agree", 2 as "Agree", 3 as "Disagree" and 4 as "Strongly disagree". The data was analysed using frequency counts, percentages.

\section{$3 \quad$ Findings and Interpretation}

The findings of the study are summarised in Tables 1 through 4. 
Table 1. Role of Digitization in Teaching and Learning of Chemistry and Mathematics in ODL

\begin{tabular}{|c|c|c|c|c|c|}
\hline & SA & A & SD & $\mathrm{D}$ & Total \\
\hline Internet is used for other purposes apart from learning/ teaching & $80(66 \%)$ & $37(30 \%)$ & $4(3 \%)$ & $1(1 \%)$ & $122(100 \%)$ \\
\hline Computer Based Test or examination is taken/given & $46(38 \%)$ & $53(43 \%)$ & $13(11 \%)$ & $10(8 \%)$ & $122(100 \%)$ \\
\hline Projected lectures are taken/ given & $42(34 \%)$ & $50(41 \%)$ & $13(11 \%)$ & $17(14 \%)$ & $122(100 \%)$ \\
\hline Video lessons are watched/made & $31(25 \%)$ & $46(38 \%)$ & $18(15 \%)$ & $27(22 \%)$ & $122(100 \%)$ \\
\hline There is online interaction with lecturers/ students & $31(25 \%)$ & $47(39 \%)$ & $20(16 \%)$ & $24(20 \%)$ & $122(100 \%)$ \\
\hline Digital Whiteboard is used for Digital Classroom learning/ teaching & $30(25 \%)$ & $60(49 \%)$ & $20(16 \%)$ & $12(10 \%)$ & $122(100 \%)$ \\
\hline Virtual library is used to make researches & $32(26 \%)$ & $51(42 \%)$ & $21(17 \%)$ & $18(15 \%)$ & $122(100 \%)$ \\
\hline The respondent is aware of online tests & $48(39 \%)$ & $54(44 \%)$ & $8(7 \%)$ & $12(10 \%)$ & $122(100 \%)$ \\
\hline Online assignments are used in the Institute & $52(42 \%)$ & $57(47 \%)$ & $8(7 \%)$ & $5(4 \%)$ & $122(100 \%)$ \\
\hline Social media is used to interact with lecturers & $5041 \%)$ & $57(47 \%)$ & $9(7 \%)$ & $6(5 \%)$ & $122(100 \%)$ \\
\hline Online tests are better than paper tests & $25(21 \%)$ & $32(26 \%)$ & $33(27 \%)$ & $32(26 \%)$ & $122(100 \%)$ \\
\hline Online assignments are better than the others & $31(26 \%)$ & $40(33 \%)$ & $20(16 \%)$ & $31(25 \%)$ & $122(100 \%)$ \\
\hline
\end{tabular}


In Table 1, 117 of the respondents ( 80 and 37 respectively) agreed that they use the internet for other purposes apart from teaching/learning. Next, 43 of the respondents (12 and 31 respectively) representing 35\% agreed that they prefer online teaching/learning to physical contact while 79 disagreed. This shows that more of them disagreed. Then, $81 \%$ (38\% and $43 \%$ respectively) agreed that they prepare/ take Computer Based Tests. Most (87\%) of the respondents agreed that they print materials for teaching or learning. Meanwhile, $75 \%$ of them agreed that they prepare their lectures using PowerPoint/ take projected lectures. Most of these agreed that they prepare video teaching or watch video lessons. Relatedly, $74 \%$ (i.e. $25 \%$ and $49 \%$ respectively) "agreed" that they use digital whiteboards. Furthermore, $64 \%$ (i.e. $25 \%$ and $39 \%$ respectively) of the respondents "agreed" that they interact online. Interestingly, 106 respondents, representing $87 \%$, "agreed" that they source for teaching/ learning materials online. Most of the respondents "agreed" that they use the virtual library to do research. A similar trend of results was found with regard to online tests, use of social media, use of management information systems and the uploading/ downloading of online modules. Collectively considered, the findings in Table 1 suggest appreciable adoption of ICT at the Distance Learning Institute of the University of Lagos. However, most (77\%) of the respondents indicated that the Institute had not given them training in the area of digitisation and computer technology. 
Table 2. Challenges in Digitization

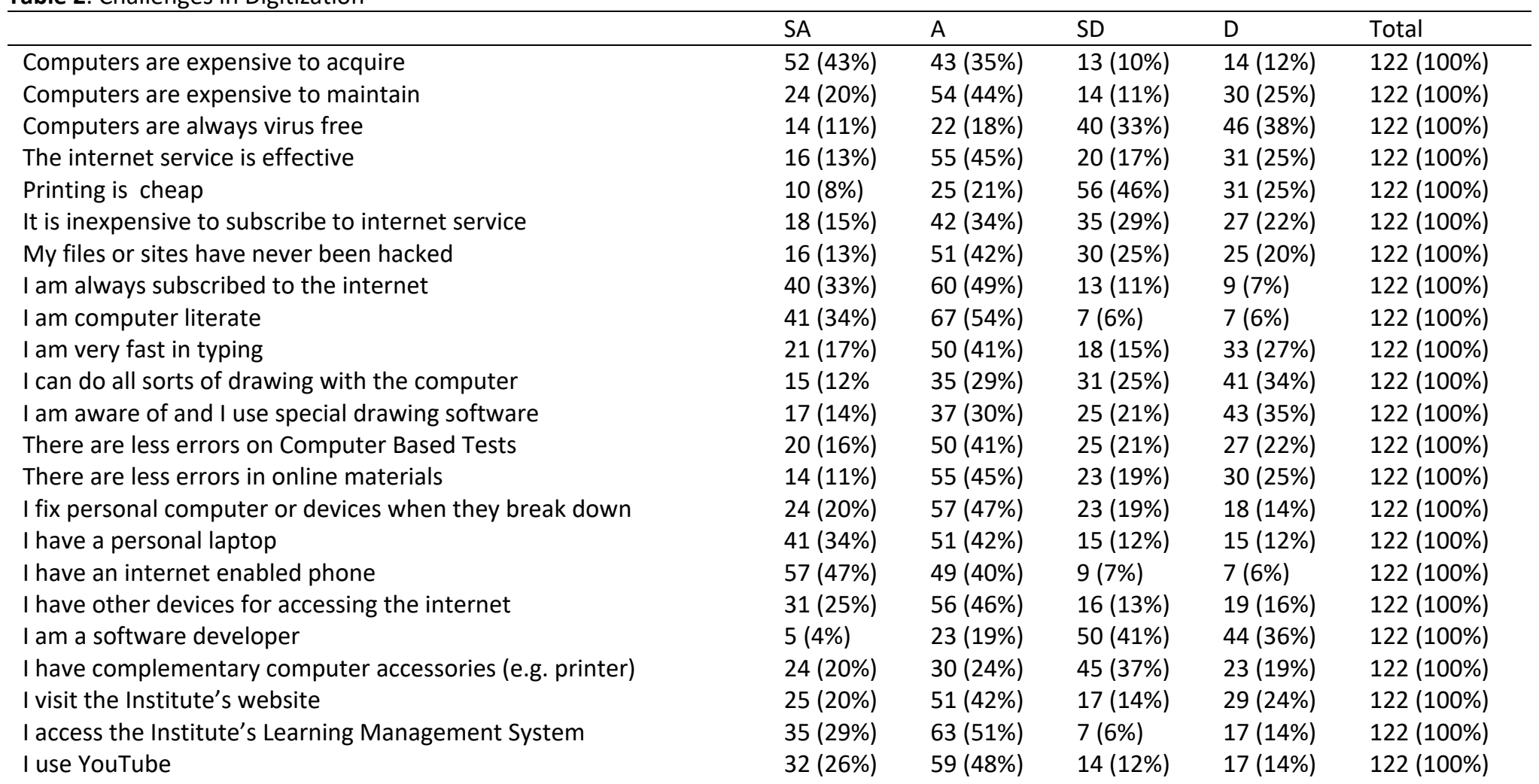




\begin{tabular}{|c|c|c|c|c|c|}
\hline My internet provider is always efficient & $21(17 \%)$ & $57(47 \%)$ & $21(17 \%)$ & $23(19 \%)$ & $122(100 \%)$ \\
\hline I am good in computer programming & $12(10 \%)$ & $24(20 \%)$ & $25(20 \%)$ & $61(50 \%)$ & $122(100 \%)$ \\
\hline I am good in desktop publishing & $18(15 \%)$ & $50(40 \%)$ & $18(15 \%)$ & $36(30 \%)$ & $122(100 \%)$ \\
\hline Power supply is consistent & $13(11 \%)$ & $49(40 \%)$ & + & $27(22 \%)$ & $122(100 \%)$ \\
\hline Internet service provider has adequate network coverage & $14(12 \%)$ & $49(40 \%)$ & $21(17 \%)$ & $38(31 \%)$ & $122(100 \%)$ \\
\hline
\end{tabular}


In Table 2, the main challenges affecting digitisation were identified in the areas of acquisition, utilisation and maintenance. Most of the respondents "agreed" that computers are expensive to acquire and to maintain. Most (71\% and 51\%) of the respondents respectively indicated that "printing", "internet subscription" and computer peripherals are expensive. Only a cumulative percentage of 29 "agreed" that the computers they use are free from viruses, the inference being that viruses are a problem for majority of the respondents. Downtime resulting from erratic power supply and internet service provision was also reported. Nevertheless, on the whole, Table 2 shows significant reach and use of digitalisation equipment among the participants (notably with regard to subscription to the internet, computer literacy [including typing and troubleshooting], computer ownership and utilisation of the Institute's Learning Management System (LMS)'). This indicates a good degree of adoption of ICT at the Institute.

Table 3. Impact of Digitization on Teaching and Learning

\begin{tabular}{|c|c|c|c|c|c|}
\hline & SA & A & SD & $D$ & Total \\
\hline $\begin{array}{l}\text { Online learning/teaching is better for } \\
\text { learning all aspects of Chemistry/ } \\
\text { Mathematics }\end{array}$ & $\begin{array}{l}13 \\
(11 \%)\end{array}$ & $\begin{array}{l}46 \\
(38 \%)\end{array}$ & $\begin{array}{l}26 \\
(21 \%)\end{array}$ & $\begin{array}{l}37 \\
(30 \%)\end{array}$ & $\begin{array}{l}122 \\
(100 \%)\end{array}$ \\
\hline $\begin{array}{l}\text { The online learning/teaching is effective } \\
\text { for learning all aspects of Chemistry/ } \\
\text { Mathematics }\end{array}$ & $5(4 \%)$ & $\begin{array}{l}41 \\
(34 \%)\end{array}$ & $\begin{array}{l}48 \\
(39 \%)\end{array}$ & $\begin{array}{l}28 \\
(23 \%)\end{array}$ & $\begin{array}{l}122 \\
(100 \%)\end{array}$ \\
\hline $\begin{array}{l}\text { Computer Based Test displays all diagrams } \\
\text { and signs accurately in Chemistry/ } \\
\text { Mathematics }\end{array}$ & $8(7 \%)$ & $\begin{array}{l}54 \\
(44 \%)\end{array}$ & $\begin{array}{l}23 \\
(19 \%)\end{array}$ & $\begin{array}{l}37 \\
(30 \%)\end{array}$ & $\begin{array}{l}122 \\
(100 \%)\end{array}$ \\
\hline $\begin{array}{l}\text { ODL can do without the internet in } \\
\text { learning Chemistry/ Mathematics }\end{array}$ & $9(7 \%)$ & $\begin{array}{l}37 \\
(30 \%)\end{array}$ & $\begin{array}{l}51 \\
(42 \%)\end{array}$ & $\begin{array}{l}25 \\
(21 \%)\end{array}$ & $\begin{array}{l}122 \\
(100 \%)\end{array}$ \\
\hline $\begin{array}{l}\text { The respondent can plot graphs well using } \\
\text { the computer }\end{array}$ & $\begin{array}{l}14 \\
(12 \%)\end{array}$ & $\begin{array}{l}21 \\
(17 \%)\end{array}$ & $\begin{array}{l}39 \\
(32 \%)\end{array}$ & $\begin{array}{l}48 \\
(39 \%)\end{array}$ & $\begin{array}{l}122 \\
(100 \%)\end{array}$ \\
\hline
\end{tabular}

From Table 3, it was deduced that majority (59) of the respondents (13 and 46 respectively) being $49 \%$ agreed that Online learning is better for teaching/ learning all aspects of Chemistry/ Mathematics whereas; 63 respondents (26 and 37 respectively) being $51 \%$ (21\% and $37 \%$ respectively) did disagree with it. Furthermore, 46 respondents agreed that online learning is effective for teaching/learning all aspects of Chemistry/Mathematics. Also, 62 of the respondents, being $51 \%$, agreed that Computer Based Tests display all diagrams and signs accurately in Chemistry/ Mathematics. Up to 46 of the respondents being 37\% agreed that ODL can do without the internet in teaching and learning Chemistry/Mathematics but 76 of them (51 and 25 respectively) being $63 \%$ (42\% and $21 \%$ respectively) disagreed with it. Lastly; 35 respondents (14 and 21 
respectively) being $29 \%$ (12\% and $17 \%$ respectively) agreed that They can plot graphs well using the computer then 87 of them (39 and 48 respectively) being $71 \%$ (32\% and $39 \%$ respectively) disagreed.

Table 4. Encouragement of Digitization in Teaching and Learning

\begin{tabular}{|c|c|c|c|c|c|}
\hline & SA & $A$ & SD & $\mathrm{D}$ & Total \\
\hline $\begin{array}{l}\text { Institute provides time-to-time } \\
\text { orientation on latest trends in } \\
\text { digitization }\end{array}$ & $\begin{array}{l}30 \\
(25 \%)\end{array}$ & $\begin{array}{l}48 \\
(39 \%)\end{array}$ & $\begin{array}{l}23 \\
(19 \%)\end{array}$ & $\begin{array}{l}21 \\
(17 \%)\end{array}$ & $\begin{array}{l}122 \\
(100 \%)\end{array}$ \\
\hline $\begin{array}{l}\text { The Institute provides financial support } \\
\text { to acquire devices }\end{array}$ & $7(6 \%)$ & $\begin{array}{l}20 \\
(16 \%)\end{array}$ & $\begin{array}{l}59 \\
(48 \%)\end{array}$ & $\begin{array}{l}36 \\
(30 \%)\end{array}$ & $\begin{array}{l}122 \\
(100 \%)\end{array}$ \\
\hline $\begin{array}{l}\text { The Institute provides free and } \\
\text { functional internet for researchers }\end{array}$ & $\begin{array}{l}10 \\
(8 \%)\end{array}$ & $\begin{array}{l}28 \\
(23 \%)\end{array}$ & $\begin{array}{l}45 \\
(37 \%)\end{array}$ & $\begin{array}{l}39 \\
(32)\end{array}$ & $\begin{array}{l}122 \\
(100 \%)\end{array}$ \\
\hline $\begin{array}{l}\text { The Institute has stand-by engineers and } \\
\text { programmers to attend to breakdowns }\end{array}$ & $\begin{array}{l}11 \\
(9 \%)\end{array}$ & $\begin{array}{l}51 \\
(42 \%)\end{array}$ & $\begin{array}{l}26 \\
(21 \%)\end{array}$ & $\begin{array}{l}34 \\
(28 \%)\end{array}$ & $\begin{array}{l}122 \\
(100 \%)\end{array}$ \\
\hline $\begin{array}{l}\text { Institute sends staff and students abroad } \\
\text { for professional training in digitisation }\end{array}$ & $\begin{array}{l}11 \\
(9 \%)\end{array}$ & $\begin{array}{l}36 \\
(30 \%)\end{array}$ & $\begin{array}{l}49 \\
(40 \%)\end{array}$ & $\begin{array}{l}26 \\
(21 \%)\end{array}$ & $\begin{array}{l}122 \\
(100 \%)\end{array}$ \\
\hline $\begin{array}{l}\text { There is consistent power supply in the } \\
\text { Institute }\end{array}$ & $\begin{array}{l}26 \\
(21 \%)\end{array}$ & $\begin{array}{l}60 \\
(49 \%)\end{array}$ & $\begin{array}{l}21 \\
(18 \%)\end{array}$ & $\begin{array}{l}15 \\
(12 \%)\end{array}$ & $\begin{array}{l}122 \\
(100 \%)\end{array}$ \\
\hline $\begin{array}{l}\text { The Institute has devices for digital } \\
\text { classrooms }\end{array}$ & $\begin{array}{l}17 \\
(14 \%)\end{array}$ & $\begin{array}{l}61 \\
(50 \%)\end{array}$ & $\begin{array}{l}20 \\
(16 \%)\end{array}$ & $\begin{array}{l}24 \\
(20 \%)\end{array}$ & $\begin{array}{l}122 \\
(100 \%)\end{array}$ \\
\hline $\begin{array}{l}\text { The Institute has enhanced digital } \\
\text { devices }\end{array}$ & $\begin{array}{l}18 \\
(14 \%)\end{array}$ & $\begin{array}{l}63 \\
(52 \%)\end{array}$ & $\begin{array}{l}21 \\
(18 \%)\end{array}$ & $\begin{array}{l}20 \\
(16 \%)\end{array}$ & $\begin{array}{l}122 \\
(100 \%)\end{array}$ \\
\hline
\end{tabular}

In Table 4, 78 respondents (30 and 48 respectively) being 64\% (25\% and 39\% respectively) agreed that the Institute provides time-to-time orientation for them on latest trends in digitization as 44 of them ( 23 and 21 respectively) being $36 \%$ (19\% and $17 \%$ respectively) disagreed. This shows that more of them agreed.

Meanwhile, 27 of the respondents ( 7 and 20 respectively) being $22 \%(6 \%$ and $16 \%$ respectively) agreed that The Institute provides financial support for them to acquire devices while 95 of them (59 and 36 respectively) being 78 (48\% and $30 \%$ respectively) disagreed. Therefore, more of them disagreed.

In reference to the table also, 38 respondents (10 and 28 respectively) being $31 \%(8 \%$ and $23 \%$ respectively agreed that The Institute provides free and functional internet for their research but 84 of them (45 and 39 respectively) being $69 \%$ (37\% and 32\% respectively) disagreed. So because of this, more respondents disagreed.

Then, 62 respondents ( 11 and 51 respectively) being 51\% (9\% and $42 \%$ respectively) did agree that The Institute has stand-by engineers and programmers to attend to breakdowns hence; 60 of them (26 and 34 respectively) being $49 \%$ ( $21 \%$ and $28 \%$ respectively) disagreed. This proves that more of the respondents agreed. 
Additionally; 47 respondents (11 and 36 respectively) being 39\% (9\% and $30 \%$ respectively) agreed that The Institute takes them outside the country on excursion or professional training on digitization related conferences and workshops although 75 of them (49 and 26 respectively) amounting to $61 \%$ (40\% and $21 \%$ respectively) was of contrary view as they disagreed. With this, more of the respondents disagreed.

Also, 86 respondents (26 and 60 respectively) as $70 \%$ (21\% and $49 \%$ respectively) agreed that There is consistent power supply in the Institute but 36 of them (21 and 15 respectively) being 30\% (18\% and 12\% respectively) disagreed. In consideration of this, more of the respondents agreed strongly with it.

With respect to the same table of information, 78 of the respondents (17 and 61 respectively) being $64 \%$ (14\% and 50\% respectively) agreed that The Institute has devices for digital classrooms while 44 of them (20 and 24 respectively) being $36 \%$ ( $16 \%$ and $20 \%$ respectively) gave negative responses in disagreement. So, more of the respondents agreed.

Lastly on the table, 81 respondents (18 and 63 respectively) being 66\% (14\% and $52 \%$ respectively) agreed that The Institute has enhanced digital devices and 41 of them ( 21 and 20 respectively) being $34 \%$ (18\% and $16 \%$ respectively) disagreed. As a result, more of the respondents agreed.

\section{Summary, Conclusions and Recommendations}

Also, results from research question two clearly revealed that there were challenges encountered by Chemistry and Mathematics students and lecturer in the use of or/and acquiring and maintenance of digitization tools in the ODL. From the responses, although most of the respondents had access to digitization devices and even the internet but are very limited in use of most essential packages that aid teaching and learning such as PowerPoint, videography, programming languages, graphics designing, desktop publishing and some others. They also in higher number decried the inefficiency of internet services amongst high cost of acquisition and maintenance of digitization tools. However, this is partly responsible for digitization utilization in teaching and learning of Chemistry and Mathematics in the Institute.

More so, from the results obtained from research question three, responses gathered from the selected respondents proved that digitization generally goes a long way in having positive impacts in teaching and learning comparing to Chemistry and Mathematics but cannot be solely relied on in effective delivery of teaching and learning of Chemistry and Mathematics due to the technicalities of explaining and understanding of the two learning areas especially considering 
the calculations, signs and diagrams that are both technical to draw, analyse and understand. The contributing factors to this kind of result are unreliable power supply, limitations on the lecturers and students in advanced digitization use, non-availability of advanced but easy-to-use digitization tools and others.

Lastly, result gotten from research question four suggested that the Distance Learning Institute, University of Lagos, Akoka still has a lot more to do in empowering and encouraging her Chemistry and Mathematics students and lecturers in up-to-date possession of contemporary digitization tools and current exposure to trending advancements in digitization. Evidences from the research question fours proved that the Institute needs to do more in providing time-totime orientation for her students and staff on latest trends in digitation, provision of financial support for them to acquire devices, provision of consistent and effective free internet access, employment of proficient standby engineers and programmers to attend to hardware and software breakdowns, expose them across the borders of the country for foreign trainings, improve on consistent power supply and acquire more contemporary digitization devices.

The foregoing analyses show that a lot more needs to be done to sustain optimally; the desired impacts of digitization in teaching and learning of Chemistry and Mathematics in Open Distance Learning (ODL)

The findings revealed that digitization still suffered some constraints in the teaching and learning of Chemistry and Mathematics in ODL. A significant relationship between digitization and teaching and learning of Chemistry and Mathematics in ODL was established, which suggests that the more the application of digitization, the more effective the teaching and learning of Chemistry and Mathematics gets. So it is concluded that digitization is a critical variable in the teaching and learning of Chemistry and Mathematics in ODL. More funds and trainings were needed to further empower the ODL students and their lecturers because it is one thing to have tools for digitization and another thing to have capable manpower to utilize them. The inadequacy of power supply and inefficient internet service provision were both threats to maximal impacts of digitization. Therefore, it was concluded that the Distance Learning Institute of the University of Lagos is not yet ready for heightened adoption of digitization in its operations.

Based on these conclusions, it is recommended that continuous in-house and external training of lecturers and orientation of students on up-to-date embracement of digitization be conducted. Development and training of digitization experts who are specifically prepared for instructional design and development and who will work in partnership with the Institute for parallel consistency in the use and maintenance of digitization tools is also recommended. It is recommended that the Institute generates its own power supply off the national grid to ensure consistent power supply. Partnership with standby internet service providers, to ensure regular internet service provision, is 
also recommended. Finally, improvement in support to Chemistry and Mathematics students and lecturers in acquisition of digitization tools and frequent exposure to modern improvements through soft loans, subsidies in purchase or training, payment on instalment for devices is also recommended.

\section{Bibliography}

American Institute for Conservation. (2013). Code of ethics.

Bee, R. (2008). The importance of preserving paper-based artefacts in a digital age. The Library Quarterly, 78 (2), 179-194.

Berger, S. (2009). The evolving ethics of preservation: Redefining practices and responsibilities in the 21 st century. The Serials Librarian, 57 (1), 57-68.

Brand, S. (1999). Escaping the digital Dark Age. Library Journal, 124 (2), 46-48.

Conway, P. (2010). Preservation in the age of Google: Digitization, digital preservation, and dilemmas.

Library Quarterly, 80 (1), 61-79.

Dubin, D., Futrelle, J., Plutchak, J., \& Eke, J. (2009). Preserving meaning, not just objects: Semantics and digital preservation. Library Trends, 57 (3), 595610.

Galloway, P. (2009). Digital archiving. In Encyclopaedia of Library and Information Sciences. (1518-1527). Taylor \& Francis.

Gladney, H. M. (2009). Long-term preservation of digital records: Trustworthy digital objects. The American Archivist, 72 (2), 401-435.

Gracy, K. F., \& Kahn, M. B. (2012). Preservation in the digital age. Library Resources \& Technical Services, 56 (1), 25-43.

Kastellec, M. (2012). Practical limits to the scope of digital preservation. Information Technology \& Libraries, 31 (2), 63-71.

Lasfargues, F., Martin, C., and Medjkoune, L. (2012). Archiving before losing valuable data? Development of web archiving in Europe. Bibliothek Forschung Und Praxis, 36 (1), 117-124.

Maberry, S. E. (2009). Archiving 2.0: Problems, possibilities, and the expanding role of librarians. Art Documentation, 28 (1), 40-43.

Routhier Perry: Digitization and Digital Preservation Published by SJSU Scholar Works, 2014

Moghaddam, G. G. (2010). Preserving digital resources: Issues and concerns from a view of librarians. Collection Building, 29 (2), 65-69. 